\title{
Formation of Dihydroxybenzenes in Cigarette Smoke. Part 1. Contribution from Chlorogenic Acid and Rutin *
}

\author{
by \\ Michael F. Davis, Huey D. Mills, and Serban C. Moldoveanu \\ R.J. Reynolds Tobacco Co., Winston-Salem, NC 27105, USA
}

\section{SUMMARY}

Catechol and alkylcatechols are known co-carcinogens present in cigarette smoke. Hydroquinone, although nongenotoxic, can form a metabolite with nephrotoxic properties and is a potential human carcinogen. The formation of dihydroxybenzenes during smoking originates with the pyrolysis of several precursors from tobacco. These include cellulose, chlorogenic acid, rutin, etc. The present study attempts to quantitate the contribution of chlorogenic acid and rutin to the formation of dihydroxybenzenes and of some alkyldihydroxybenzenes. Also it estimates the contribution to the formation of dihydroxybenzenes from other potential precursors including glucose, fructose, sucrose, cellulose, pectin, starch, and lignin. The study was done in three parts: 1 . pyrolytic evaluation of the amount of dihydroxybenzenes in smoke generated from isolated potential precursors; 2 . analysis of smoke from cigarettes made from a variety of tobaccos (14 single grades) and two blended cigarettes, followed by correlations of dihydroxybenzenes yield with the tobacco content of various suspected precursors; 3 . addition of chlorogenic acid or rutin to several tobaccos followed by the smoking of the spiked cigarettes and measurement of dihydroxybenzenes yield increase. The study shows that for a variety of singlegrade cigarettes and for two blended cigarettes (one being the 2R4F Kentucky reference), the contribution of chlorogenic acid and of rutin to the formation of catechol and hydroquinone in smoke depends on the blend. For the $2 \mathrm{R} 4 \mathrm{~F}$ cigarette, the contribution from chlorogenic acid is $8.7 \%$ for catechol, and $7.7 \%$ for hydroquinone (for ISO smoking protocol). For the same cigarette, the contribution from rutin is $3.7 \%$ for catechol and $5.1 \%$ for hydro- quinone. The results of the study are in agreement with a previously reported finding indicating that chlorogenic acid contributes about $13 \%$ to the catechol formation in smoke for the 1R1 Kentucky reference cigarette. The study results suggest that other components in tobacco, besides chlorogenic acid, rutin, glucose, fructose, sucrose, cellulose, pectin, starch, and lignin are major contributors to the formation of catechol and hydroquinone in cigarette smoke. [Beitr. Tabakforsch. Int. 25 (2012) 396-408]

\section{ZUSAMMENFASSUNG}

Catechol und Alkylcatechole sind bekannte Kokarzinogene im Zigarettenrauch. Hydrochinon, obwohl nicht-genotoxisch, kann einen Metaboliten mit nephrotoxischen Eigenschaften bilden und ist potenziell karzinogen für den Menschen. Die Entstehung von Dihydroxybenzolen beim Rauchen beginnt mit der Pyrolyse mehrerer Vorläufer aus dem Tabak. Dazu gehören Cellulose, Chlorogensäure, Rutin usw. Die vorliegende Studie versucht den Beitrag von Chlorogensäure und Rutin zur Bildung von Dihydroxybenzolen sowie von einigen Alkyldihydroxybenzolen zu quantifizieren. Außerdem wird der Beitrag von anderen potenziellen Vorläufern zur Bildung von Dihydroxybenzolen untersucht, darunter Glucose, Fructose, Sucrose, Cellulose, Pektin, Stärke und Lignin. Die Studie bestand aus drei Teilen: 1. pyrolytische Untersuchung der Menge von Dihydroxybenzolen in Rauch, die aus isolierten potenziellen Vorläufern entsteht; 2. Rauchanalyse von Zigaretten aus jeweils einer Tabaksorte (14 einzelne Qualitätsstufen) und zwei Zigaretten mit Tabakmischungen, anschließend Korrelationen der Ausbeute an Dihydroxybenzolen mit dem Tabakgehalt diverser vermuteter Vorläufer; 
3. Beimengung von Chlorogensäure oder Rutin zu unterschiedlichem Tabak, anschließend Abrauchen der so präparierten Zigaretten und Messung des Anstiegs der Ausbeute an Dihydroxybenzolen. Die Untersuchung ergab, dass bei einer Reihe von Zigaretten aus einer einzigen Sorte und bei zwei Zigaretten aus Tabakmischungen (eine davon die Kentucky-Referenzzigarette 2R4F) der Beitrag von Chlorogensäure und Rutin zur Entstehung von Catechol und Hydrochinon in Rauch von der Mischung abhängt. Bei der 2R4F-Zigarette beträgt der Beitrag von Chlorogensäure 8,7\% für Catechol und 7,7\% für Hydrochinon (für ISO-Rauchprotokoll). Bei derselben Zigarette beträgt der Beitrag von Rutin 3,7\% für Catechol und 5,1\% für Hydrochinon. Die Ergebnisse der Studie stimmen mit früher berichteten Informationen überein, nach denen Chlorogensäure bei der Kentucky-Referenzzigarette 1R1 etwa 13\% zur Bildung von Catechol im Rauch beiträgt. Die Studienergebnisse lassen erkennen, dass andere Bestandteile des Tabaks, abgesehen von Chlorogensäure, Rutin, Glucose, Fructose, Sucrose, Cellulose, Pektin, Stärke und Lignin einen wichtigen Beitrag zur Entstehung von Catechol und Hydrochinon in Zigarettenrauch leisten. [Beitr. Tabakforsch. Int. 25 (2012) 396-408]

\section{RESUME}

Le catéchol et les alkylcatéchols sont connus en tant que co-carcinogènes présents dans la fumée de cigarette. L'hydroquinone, bien que non génotoxique, peut former un métabolite ayant des propriétés néphrotoxiques et est potentiellement carcinogène pour l'homme. La formation de dihydroxybenzènes par une cigarette en ignition provient de la pyrolyse de plusieurs précurseurs du tabac. Ils incluent la cellulose, l'acide chlorogénique, la rutine, etc. La présente étude tente de quantifier la contribution de l'acide chlorogénique et de la rutine dans la formation de dihydroxybenzènes et de certains alkyldihydroxybenzènes. Par ailleurs, l'étude présente une estimation de la contribution à la formation des dihydroxybenzènes à partir d'autres précurseurs potentiels, notamment le glucose, le fructose, le saccharose, la cellulose, la pectine, l'amidon et la lignine. L'étude est composée de trois parties: 1. l'évaluation pyrolytique de la quantité de dihydroxybenzènes dans la fumée générée à partir des précurseurs potentiels isolés; 2. l'analyse de la fumée de cigarettes fabriquées à partir d'une variété de tabacs (14 qualités différentes) et de deux types de cigarettes composées d'un mélange de tabacs, suivie des mises en corrélation entre les teneurs en dihydroxybenzènes et la présence des précurseurs divers suspectés dans le tabac; 3 . l'addition d' acide chlorogénique ou de rutine à plusieurs tabacs, suivie par le fumage des cigarettes enrichies et la mesure de l'augmentation de la teneur en dihydroxybenzènes. L'étude montre que pour une variété de cigarettes composées d'une seule qualité de tabac et pour deux types de cigarettes composées d'un mélange (l'une étant la référence 2R4F Kentucky), la contribution de l'acide chlorogénique et de la rutine dans la formation du catéchole et de l'hydroquinone dans la fumée dépend du mélange. Pour la cigarette 2R4F, l'acide chlorogénique intervient à hauteur de $8,7 \%$ pour le catéchole et à hauteur de $7,7 \%$ pour l'hydroquinone (pour la méthode de fumage normalisée ISO). Pour la même cigarette, la rutine intervient à hauteur de $3,7 \%$ pour le catéchole et à hauteur de $5,1 \%$ pour l'hydroquinone. Les résultats de l'étude coïncident avec une conclusion précédemment rapportée indiquant que l'acide chlorogénique intervient à hauteur de $13 \%$ dans la formation du catéchole présent dans la fumée pour la cigarette de référence 1R1 Kentucky. Les résultats de l'étude suggèrent que d'autres composants du tabac, à côté de l'acide chlorogénique, de la rutine, du glucose, du fructose, du saccharose, de la cellulose, de la pectine, de l'amidon et de la lignine contribuent largement à la formation du catéchole et de l'hydroquinone dans la fumée de cigarette. [Beitr. Tabakforsch. Int. 25 (2012) 396-408]

KEY WORDS: cigarette smoke, catechol, chlorogenic acid, rutin

\section{INTRODUCTION}

Catechol is a known co-carcinogen present in cigarette smoke. Various studies have demonstrated that catechol and alkylcatechols are tumor promoters which increase the invasion and metastasis of lung carcinoma cells (1-3). Hydroquinone, also present in cigarette smoke, generally tests negative in standard mutagenicity assays. However, in mammals this compound is metabolized to 2,3,5-(trisglutathione-S-yl)hydroquinone (4) that is a nephrotoxic metabolite with proven carcinogenic properties in rats and therefore is a potential human carcinogen (carcinogenic potency $\mathrm{TD}_{50}$ in rats is $71.5 \mathrm{mg} / \mathrm{kg} /$ day for catechol and $82.5 \mathrm{mg} / \mathrm{kg} /$ day for hydroquinone (5)). For these reasons, cigarettes generating a lower yield of dihydroxybenzenes in smoke are desirable and the evaluation of the contribution of different precursors to their formation in cigarette smoke is of considerable interest.

The formation of dihydroxybenzenes as well as other phenols and attempts to reduce their yield in cigarette smoke have been previously evaluated and reported in the literature (6-12). However, the contribution of different precursors from tobacco to the formation of these compounds in smoke is not unanimously accepted. As an example, an earlier study (7) indicated that a reduction of chlorogenic acid (3-O-caffeoylquinic acid) from $1.5-2.5 \%$ to $0.2 \%$ leads to a $50 \%$ reduction of catechol in smoke, while a different study (6) showed that chlorogenic acid was responsible for only about $13 \%$ of catechol in the smoke of Kentucky reference 1R1 cigarettes. The study performed on Kentucky reference 1R1 cigarette (6) also indicated a contribution to the formation of catechol from cellulose (7-12\%), from glucose, fructose and sucrose (4\% together), and from rutin $(<1 \%)$. These results suggested that a significant portion of catechol is formed from pectin, starch and hemicellulose. Other studies $(9,10)$, although consistent with the concept of formation of catechol from chlorogenic acid and rutin, do not provide a quantitative answer regarding the main source of catechol or other dihydroxybenzenes in cigarette smoke.

The present study describes a systematic investigation of the formation of dihydroxybenzenes in cigarette smoke from suspected precursors previously reported in the litera- 
ture: chlorogenic acid, rutin, glucose, fructose, sucrose, cellulose, pectin, starch, and lignin. The study started with separate pyrolytic evaluations on each of these compounds. The second step consisted of the analysis of smoke from cigarettes made from a variety of tobaccos (some commercial blends and some single grades) and proposes correlations of dihydroxybenzenes formation with various suspected precursors. The third step consisted of adding specific precursors (chlorogenic acid or rutin) to several tobaccos (commercial blends and selected single grades) followed by smoking the spiked cigarettes and analyzing dihydroxybenzene formation. The increase in dihydroxybenzenes yield was compared to the initial yield from cigarettes made with the same tobacco but with no addition. Conclusions on the contribution of each precursor to dihydroxybenzenes formation are proposed.

\section{EXPERIMENTAL}

Three different types of experiments were necessary for generating results for this study. One type of experiment was the pyrolysis of pure compounds suspected to be precursors for catechol and other dihydroxybenzenes. The second type of experiment was the analysis of polyphenols in tobaccos, and the third was the analysis of catechol and hydroquinone in smoke from cigarettes made with tobaccos previously analyzed for polyphenols. Some of the cigarettes used in this study were commercially available, other cigarettes were made in a pilot plant at R.J. Reynolds Tobacco Co., and the other cigarettes were handmade.

\section{Experimental conditions for pyrolysis}

For the pyrolysis of the samples evaluated in this study, a filament pyrolyzer Pyroprobe 5000 with a 5250-T autosampler (CDS Analytical Inc., Oxford, PA, USA) was used. Pyrolysis was performed using the parameters given in Table 1. The pyrolyzer was on line with a 6890/5973 GC/MS instrument (Agilent, Wilmington, DE, USA). The GC/MS analysis of the pyrolyzates was performed using the parameters described in Table 2. The DB-1701 type GC column (Agilent / J\&W Scientific, Wilmington, DE, USA) has medium polarity and separates well low molecular weight components of the pyrolyzates. Although reliable qualitative information can be obtained using GC/MS analysis of pyrolyzates, this does not generate information on the whole set of constituents of the pyrolyzate. The pyrolysis products typically consist of a mixture of volatile compounds, semivolatiles, and also of char. The analysis

Table 1. Parameters for the production of pyrolyzates.

\begin{tabular}{ll}
\hline Parameter & Description \\
\hline Pyrolysis gas & Helium \\
Initial temperature & $275^{\circ} \mathrm{C}$ \\
Initial time & $10 \mathrm{~s}$ \\
Heating rate & $20^{\circ} \mathrm{C} / \mathrm{ms}$ \\
Final temperature & $900^{\circ} \mathrm{C}$ \\
Pyrolysis time & $20 \mathrm{~s}$ \\
Purging time & $30 \mathrm{~s}$ \\
Sample weight & $1 \mathrm{mg} \pm 0.03 \mathrm{mg}$ \\
\hline
\end{tabular}

Table 2. Parameters for the GC/MS on-line analysis of pyrolyzates.

\begin{tabular}{ll}
\hline Parameter & Description \\
\hline GC column & DB-1701 \\
Column dimensions & $60 \mathrm{~m}$ long, $0.25 \mathrm{~mm}$ id. \\
Film thickness & $1.0 \mathrm{\mu m}$ \\
Initial oven temperature & $37^{\circ} \mathrm{C}$ \\
Initial time & $4.0 \mathrm{~min}$ \\
Oven ramp rate & $2^{\circ} \mathrm{C} / \mathrm{mm}$ \\
Oven final first ramp & $60^{\circ} \mathrm{C}$ \\
Final time first ramp & $0 \mathrm{~min}$ \\
Oven ramp rate & $5^{\circ} \mathrm{C} / \mathrm{mm}$ \\
Oven final temperature & $280^{\circ} \mathrm{C}$ \\
Final time & $20 \mathrm{~min}$ \\
Total run time & $75.5 \mathrm{~min}$ \\
Inlet temperature & $280^{\circ} \mathrm{C}$ \\
Inlet mode & $\mathrm{Split}$ \\
Carrier gas & $\mathrm{Helium}$ \\
Flow mode & $\mathrm{Constant} \mathrm{flow}$ \\
Flow rate & $1.1 \mathrm{~mL} / \mathrm{min}$ \\
Nominal initial pressure & $17.5 \mathrm{psi}$ \\
Split ratio & $70: 1$ \\
Split flow & $76.0 \mathrm{~mL} / \mathrm{min}$ \\
GC outlet & $\mathrm{MSD}$ \\
Outlet pressure & Vacuum \\
MSD transfer line temperature & $280^{\circ} \mathrm{C}$ \\
lon source temperature & $230^{\circ} \mathrm{C}$ \\
Quadrupole temperature & $150^{\circ} \mathrm{C}$ \\
MSD EM offset & $250 \mathrm{~V}$ \\
MSD solvent delay & $2.0 \mathrm{~min}$ \\
MSD acquisition mode & $\mathrm{TIC}$ \\
Mass range & $29-550$ a.u. \\
\hline &
\end{tabular}

by GC/MS is done only on the volatile compounds and part of the semivolatiles. Therefore, the assumption that all pyrolysis products of the initial material are represented in the chromatogram of the pyrolyzate (pyrogram) leads to erroneous results. Also, in a GC/MS analysis, the compounds in a mixture have different response factors to the MS detector. Therefore, even for volatile compounds, it is not possible to obtain quantitative results without a specific calibration. Nevertheless, peak areas in a pyrogram can be utilized for obtaining semi-quantitative estimations regarding the relative yield of a specific compound, because they depend on the amount of the generated compound. These areas were used in this study for yield estimations of catechol and hydroquinone.

Experimental conditions for polyphenols analysis in tobacco

The analysis of tobacco for chlorogenic acid and rutin was done using an HPLC procedure. The chemicals for this procedure were chlorogenic acid, rutin, acetic acid, and sodium acetate, and were obtained from Sigma-Aldrich (St. Louis, MO, USA). The methanol was from Fisher Scientific LLC (Suwanee, GA, USA). Tartrazine (FD\&C Yellow \#5) was used as an internal standard and was obtained from Spectrum Chemical Mfg. Corp. (Gardena, CA, USA).

For the analysis, a $0.1 \mathrm{~g}$ tobacco sample was weighed with a precision of $0.1 \mathrm{mg}$ in a $20-\mathrm{mL}$ screw-cap vial. To the vial was added $5 \mathrm{~mL}$ extracting solution, and the vials were shaken for $30 \mathrm{~min}$ on a vortex type shaker VWR VX2500 (Henry Troemner LLC, Thorofare, NJ, USA). The extracting solution consisted of a mixture $60: 40$ of 
methanol:water (v:v) that contain $125 \mu \mathrm{g}$ tartrazine/mL. After the extraction, the solutions were filtered through a $0.45 \mathrm{~mm}$ PVDF Whatman Autovial (Whatman, Clifton, NJ, USA). Once extracted, the samples should be analyzed as soon as possible and it is not recommended to keep the samples longer than one day at room temperature or more than 3 days in a refrigerator. The HPLC analysis was performed on a 1100 Series HPLC system from Agilent (Wilmington, DE, USA) with a degasser, quaternary pump, injector, column heater, and UV detector. The system was equipped with a Gemini $5 \mu \mathrm{C} 18110 \mathrm{~A}$ column, $150 \mathrm{~mm} \times 2 \mathrm{~mm}$ from Phenomenex (Torrance, CA, USA). The injection volume was $5 \mu \mathrm{L}$. The column heater was set at $28{ }^{\circ} \mathrm{C}$. An absorption spectrum for each analyte was separately recorded, and maximum absorption for chlorogenic acid was at $340 \mathrm{~nm}$ and for rutin was at $360 \mathrm{~nm}$. However, the analytical measurements were done at $340 \mathrm{~nm}$ for the analytes, and at $435 \mathrm{~nm}$ for the internal standard.

The separation used a methanol / aqueous buffer. The buffer with $\mathrm{pH}=4.4$ was made using $5.28 \mathrm{~g}$ sodium acetate and $8.16 \mathrm{~g}$ acetic acid in $4.0 \mathrm{~L}$ water. The $\mathrm{pH}$ was further adjusted to 4.4 using either acetic acid or a solution of $50 \% \mathrm{NaOH}$. The $\mathrm{pH}$ measurement was done using a calibrated Accumet AR20 pH-meter from Fisher Scientific. In order to avoid bacterial growth during storage, $0.1 \mathrm{~g} \mathrm{NaN}_{3}$ was added to the buffer. The gradient program started with $5 \%$ methanol for $0.5 \mathrm{~min}$, then went to $60 \%$ methanol at $19 \mathrm{~min}, 65 \%$ methanol at $21 \mathrm{~min}$ and back to $5 \%$ methanol at $21.5 \mathrm{~min}$, with a $3.5 \mathrm{~min}$ column re-equilibration. The flow rate was $0.7 \mathrm{~mL} / \mathrm{min}$.

Standard stock solutions for chlorogenic acid were prepared in 60:40 methanol:water, and the standard stock solutions for rutin were prepared in methanol. These solutions had the following concentrations: chlorogenic acid $618.4 \mu \mathrm{g} / \mathrm{mL}$, rutin $642.0 \mu \mathrm{g} / \mathrm{mL}$. The calculation of the results was done using calibration curves plotting $\mu \mathrm{g} / \mathrm{mL}$ analyte versus the peak area of the analyte. The peak area of the internal standard was used only to verify the reproducibility of the analysis, and the peak areas of the analytes were not normalized by the internal standard. The linearity for the calibrations was shown to be very good for the following range: chlorogenic acid between $206.1 \mu \mathrm{g} / \mathrm{mL}$ and $3.2 \mu \mathrm{g} / \mathrm{mL}$, and rutin between $214.0 \mu \mathrm{g} / \mathrm{mL}$ and $3.3 \mu \mathrm{g} / \mathrm{mL}$. All calibrations curves showed a $\mathrm{R}^{2}$ better than 0.9995 . It is likely that this linearity holds for a wider range, but in this study it was directly verified only for the specified values. The validation of the analytical procedure was not performed beyond the previously specified range. The precision of the method can be concluded based on the very high $\mathrm{R}^{2}$ values of the calibration, but it was not directly measured. Injections repeated five times for the next to lowest standard showed a relative standard deviation value less than $2 \%$.

Experimental conditions for the analysis of catechol, hydroquinone, and alkylcatechol in smoke

For this analysis, the first step was cigarette smoking. The smoke from the cigarettes was collected using a Cerulean SM 450 smoking machine (Cerulean, Linford Wood East, MK14 6LY, UK). For the main part of the study the smok- ing was performed under one regimen using $35 \mathrm{~mL}$ puff volume, $2 \mathrm{~s}$ puff, and $60 \mathrm{~s}$ puff interval, with the cigarette filters not having the ventilation blocked (indicated as ISO). The machine airflows were tuned for ISO conditions $(13,14)$. Smoke from five cigarettes was collected in each run on a 44-mm dia. Cambridge pad. For one commercial cigarette, the smoking was also performed using intensive smoking protocols. One intensive regimen used $55 \mathrm{~mL}$ puff volume, 2 s puff, and $30 \mathrm{~s}$ puff interval with $100 \%$ vent block for the cigarette (indicated as Health Canada Intensive or HCA), and the other intensive regimen used $45 \mathrm{~mL}$ puff volume, $2 \mathrm{~s}$ puff, and $30 \mathrm{~s}$ puff interval with $50 \%$ vent block for the cigarette (indicated as Massachusetts / Texas or MTX). For intensive regimens, the smoke from only three cigarettes was collected on the Cambridge pad. The pads were further extracted on a mechanical shaker for $30 \mathrm{~min}$ with $25 \mathrm{~mL}$ water containing $1 \%$ acetic acid, $0.1 \%$ ascorbic acid, and $4.5 \mu \mathrm{g} / \mathrm{mL}$ vanillic acid, used as an internal standard (all from Aldrich/Sigma, Milwaukee, WI, USA). An aliquot from the extract was filtered through a $0.45 \mu \mathrm{m}$ pore size polyvinylidene fluoride (PVDF) filter. For the HPLC analysis the extract was further diluted with extracting solution in the ratio of $1: 3$. The analysis by HPLC/fluorescence detection followed a procedure described in the literature (15) on a 1100 Series HPLC system from Agilent (Wilmington, DE, USA) with a degasser, quaternary pump, injector, column heater, and fluorescence detector. For the quantitation of phenols, calibration curves were generated using a series of four standards. In a modification of the procedure described in the literature (15), the internal standard 4-chlorophenol was replaced with vanillic acid.

For the analysis of alkyldihydroxybenzenes, a GC/MS procedure was utilized, following the procedure described in the literature (15). The 4-chlorophenol recommended as chromatographic standard in reference (15) was replaced with vanillic acid, and the ions for its detection were $\mathrm{m} / \mathrm{z}=312$ for measurement and $\mathrm{m} / \mathrm{z}=297$ for validation.

\section{RESULTS AND DISCUSSION}

\section{Pyrolysis of individual potential precursors present in tobacco}

During cigarette smoking, pyrolysis processes play an important role, and numerous attempts have been made to obtain information on smoking from pyrolysis studies (12, 16-19). In such studies, the proportion of a specific compound formed in the pyrolyzate from the initial mass of material was of considerable interest. Only rough estimations of this proportion have been obtained from pyrolytic studies. Pyrolysis results can show very good reproducibility when repeated on the same amount of sample. Due to the relatively high temperature used for the transfer of pyrolyzates into the analytical instrument (GC/MS), numerous compounds from the pyrolyzate can be analyzed. Peak areas in a pyrogram are proportional to the amount of the component which generates the peak, however the proportionality constant is not known. Therefore, comparing the peak areas for various molecular species in pyrograms generated from pure compounds offers a rea- 
Table 3. Several potential precursors of dihydroxybenzenes and their levels in tobacco.

\begin{tabular}{c|c|c|c|c|c|cc|c}
\hline Tobacco & $\begin{array}{c}\text { Chlorogenic acid } \\
(\mathrm{mg} / \mathrm{g})\end{array}$ & $\begin{array}{c}\text { Rutin } \\
(\mathrm{mg} / \mathrm{g})\end{array}$ & $\begin{array}{c}\text { Glu., fru., sucr. } \\
\text { (total) }(\%)\end{array}$ & $\begin{array}{c}\text { Cellulose+ } \\
\text { Hemicell. }(\%)\end{array}$ & $\begin{array}{c}\text { Starch } \\
(\%)\end{array}$ & $\begin{array}{c}\text { Pectin as Ca } \\
\text { pectate }(\%)\end{array}$ & $\begin{array}{c}\text { Lignin } \\
(\%)\end{array}$ \\
\hline Flue-cured & $2.0-8.0$ & $2.0-8.0$ & $15-20$ & $7-9$ & $2-3$ & $8-12$ & $1.5-3.5$ \\
Burley & $0.02-0.04$ & $0.02-0.08$ & $0.2-2.0$ & $\sim 13$ & $0.2-0.4$ & $9-14$ & $2.0-3.5$ \\
Oriental & $1.0-6.0$ & $2.0-5.0$ & $10-14$ & $\sim 11$ & $1.0-2.0$ & $6-9$ & $1.5-5.0$ \\
\hline
\end{tabular}

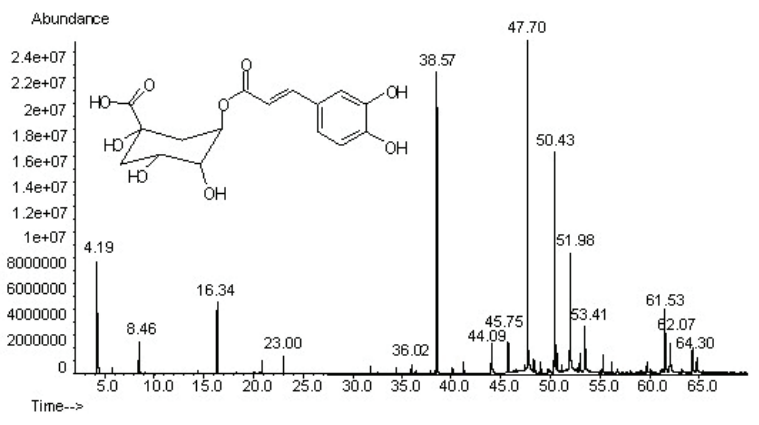

Figure 1. Pyrogram of chlorogenic acid. Peak identification by MS is given in Table 4 for each specific retention time.

sonable estimation of the yield for many compounds of interest in smoke $(12,19)$. In the present study, the first step was the production of dihydroxybenzenes by analytical pyrolysis from pure compounds that may potentially be precursors in smoke. The content range of some potential dihydroxybenzenes precursors is indicated in Table 3 for three types of tobaccos $(20-22)$.

For comparing the pyrolysis results, $0.1 \mathrm{mg}$ of catechol was pyrolyzed in triplicate and the peak areas in the pyrograms were measured. An average of those values was calculated. Catechol did not generate almost any decomposition products (18). After this, $1 \mathrm{mg}$ sample of chlorogenic acid, rutin, glucose, fructose, sucrose, cellulose, pectin (apple pectin and tobacco pectin), and lignin were separately pyrolyzed under identical conditions, but performed only in duplicate. The peak area from $0.1 \mathrm{mg}$ catechol was compared to the peak areas of all dihydroxyphenols from the pyrolyzates, and a rough estimation of the amount of these compounds in the pyrolyzates was generated. The pyrogram of $1.0 \mathrm{mg}$ chlorogenic acid (performed as indicated in the experimental part) is shown in Figure 1, and the identification of each peak resulting from MS spectra is given in Table 4. Individual peak areas normalized by the total areas are also given in Table 4.

Table 4 shows that a number of hydroxybenzenes are generated in the pyrolyzate. Because the toxicity of monohydroxybenzenes is typically limited to being corrosive and uremic toxins (23), the main interest was related to dihydroxybenzenes. By comparing peak area ratios, a rough estimation of the percent formation for different dihydroxybenzenes in the pyrolyzate from each starting material was calculated. The results as duplicate averages are given in Table 5. The relative standard deviation for the measurements of peak areas from duplicates was less than $15 \%$.

The results from Table 5 can be used to roughly estimate the yield of dihydroxybenzenes in smoke from a flue-cured cigarette made with $1 \mathrm{~g}$ tobacco and assuming a $10 \%$ transfer. These results are given in Table 6. Based on the results in Table 6, chlorogenic acid appears to be a major contributor to catechol formation in cigarette smoke, followed by cellulose and rutin. These results indicate that chlorogenic acid also contributes to the formation of hydroquinone and of other dihydroxybenzenes. Cellulose and glucose are the major contributors to the formation of hydroquinone, followed by chlorogenic acid. The total calculated levels of catechol, hydroquinone and resorcinol from Table 6 are in surprisingly good agreement with typical levels reported in the literature for these compounds in smoke for 2R4F cigarettes (23).

Table 4. Identification of the main peaks ${ }^{\mathrm{a}}$ in the chromatogram shown in Figure 1 for the pyrolysis of chlorogenic acid at $900{ }^{\circ} \mathrm{C}$.

\begin{tabular}{ll|r|r|r|r}
\hline No & Compound & $\begin{array}{r}\text { Retention time } \\
(\mathrm{min})\end{array}$ & MW & CAS\# & $\begin{array}{c}\text { Area } \\
(\%)\end{array}$ \\
\hline 1 & Carbon dioxide & 4.19 & 44 & $124-38-9$ & 11.770 \\
2 & Acetaldehyde & 5.77 & 44 & $75-07-0$ & 0.301 \\
3 & 1,3-Cyclopentadiene & 8.46 & 66 & $542-92-7$ & 1.658 \\
4 & Propanal & 8.64 & 58 & $123-38-6$ & 0.118 \\
5 & Acetone & 9.05 & 58 & $67-64-1$ & 0.089 \\
6 & 2,3-Butanedione (diacetyl) & 14.40 & 86 & $431-03-8$ & 0.236 \\
7 & 1-Methyl-1,3-cyclopentadiene & 15.62 & 80 & $96-39-9$ & 0.042 \\
8 & Benzene & 16.34 & 78 & $71-43-2$ & 4.209 \\
9 & 2-Ethylfuran & 18.26 & 96 & $3208-16-0$ & 0.090 \\
10 & 3-Methyl-3-buten-2-one & 19.98 & 84 & $814-78-8$ & 0.067 \\
11 & Acetic acid & 20.08 & 60 & $64-19-7$ & 0.208 \\
12 & 1-Penten-2-one & 20.37 & 84 & $1629-58-9$ & 0.036 \\
13 & 4-Penten-2-one & 20.60 & 84 & $13891-87-7$ & 0.091 \\
14 & Vinylfuran & 20.81 & 94 & $1487-18-9$ & 0.599 \\
\hline
\end{tabular}


Table 4. contd.

\begin{tabular}{|c|c|c|c|c|c|}
\hline No & Compound & $\begin{array}{c}\text { Retention time } \\
(\min )\end{array}$ & MW & CAS\# & $\begin{array}{c}\text { Area } \\
(\%)\end{array}$ \\
\hline 15 & Toluene & 23.00 & 92 & $108-88-3$ & 0.833 \\
\hline 16 & 3-Penten-2-one & 24.38 & 84 & $625-33-2$ & 0.097 \\
\hline 17 & Ethylbenzene & 27.74 & 106 & $100-41-4$ & 0.040 \\
\hline 18 & $p$-Xylene & 28.16 & 106 & $106-42-3$ & 0.056 \\
\hline 19 & Vinyl crotonate & 28.59 & 112 & $14861-06-4$ & 0.073 \\
\hline 20 & 2-Methyl-2-propenoic acid & 29.32 & 86 & $79-41-4$ & 0.040 \\
\hline 21 & Styrene & 29.86 & 104 & $100-42-5$ & 0.040 \\
\hline 22 & 2-Cyclopenten-1-one & 30.34 & 82 & $930-30-3$ & 0.040 \\
\hline 23 & 2-Cyclopentene-1,4-dione & 31.73 & 96 & $930-60-9$ & 0.342 \\
\hline 24 & 2-Methyl-2-cyclopenten-1-one & 32.57 & 96 & $1120-73-6$ & 0.140 \\
\hline 25 & 2-Cyclohexen-1one & 34.46 & 96 & $930-68-7$ & 0.393 \\
\hline 26 & 2-Pentenal & 36.02 & 84 & $1576-87-0$ & 0.510 \\
\hline 27 & 1,2-Cyclohexanedione & 36.44 & 112 & $765-87-7$ & 0.149 \\
\hline 28 & 2-Hydroxy-2-cyclopenten-1-one & 37.93 & 112 & $80-71-7$ & 0.360 \\
\hline 29 & 3-Methyl-2,5-furandione & 38.34 & 112 & $616-02-4$ & 0.435 \\
\hline 30 & Phenol $^{\mathrm{b}}$ & 38.57 & 94 & $108-95-2$ & 12.665 \\
\hline 31 & 2-Methylphenol & 40.15 & 108 & $95-48-7$ & 0.296 \\
\hline 32 & 3-Methylphenol & 41.22 & 108 & $108-39-4$ & 0.117 \\
\hline 33 & 4-Methylphenol & 41.28 & 108 & $106-44-5$ & 0.631 \\
\hline 34 & 1,3-Benzodioxol-2-one & 41.58 & 136 & $2171-74-6$ & 0.046 \\
\hline 35 & 5,6-Dihydro-2H-pyran-2-carboxaldehyde & 41.71 & 112 & $53897-26-0$ & 0.078 \\
\hline 36 & Dihydro-2H-pyran-2,6(3H)-dione & 42.21 & 114 & $108-55-4$ & 0.058 \\
\hline 37 & 1,4-Cyclohexandione & 42.65 & 112 & $637-88-7$ & 0.123 \\
\hline 38 & 2-Ethylphenol & 43.86 & 122 & $123-07-9$ & 0.134 \\
\hline 39 & Benzoic acid & 44.09 & 122 & $65-85-0$ & 2.254 \\
\hline 40 & 5,5-Dimethyl-2(5H)-furanone & 45.30 & 112 & 20019-64-1 & 0.062 \\
\hline 41 & 2-Coumaranone & 45.75 & 134 & $553-86-6$ & 1.240 \\
\hline 42 & 2,3-Dihydrobenzofuran & 46.32 & 120 & $496-16-2$ & 0.193 \\
\hline 43 & 1,2-Benzenediol (catechol) & 47.70 & 110 & $120-80-9$ & 18.468 \\
\hline 44 & 1-(5-Methyl-2-furanyl)-1-propanone & 48.34 & 138 & $10599-69-6$ & 0.800 \\
\hline 45 & Unknown & 49.03 & 140 & - & 0.672 \\
\hline 46 & 4-Methyl-1,2-benzenediol & 49.78 & 124 & $452-86-8$ & 0.837 \\
\hline 47 & 1,4-Benzenediol (hydroquinone) & 50.43 & 110 & $123-31-9$ & 9.685 \\
\hline 48 & Unknown & 50.60 & 156 & - & 1.382 \\
\hline 49 & 1,3-Benzenediol (resorcinol) & 51.11 & 110 & $108-46-3$ & 0.900 \\
\hline 50 & 4-Ethylcatechol & 51.98 & 138 & $1124-39-6$ & 7.954 \\
\hline 51 & 1,1'-Biphenyl-2-ol ? & 52.66 & 170 & $90-43-7$ & 0.272 \\
\hline 52 & 5-Methyl-2-furanmethanol & 52.78 & 112 & $3857-25-8$ & 0.123 \\
\hline 53 & 2-Phenoxyphenol & 52.97 & 180 & $2417-10-9$ & 1.030 \\
\hline 54 & 2-Hydroxy-5-methylisophthalaldehyde & 53.41 & 164 & $7310-95-4$ & 2.167 \\
\hline 55 & Unknown & 53.52 & 164 & - & 1.702 \\
\hline 56 & Unknown & 55.28 & 164 & - & 0.790 \\
\hline 57 & 2-Cyclohexene-1,4-diol & 56.16 & 114 & $41513-32-0$ & 0.527 \\
\hline 58 & 4,4'-Ethylidenediphenol & 56.70 & 214 & $2081-08-5$ & 0.165 \\
\hline 59 & 7-Hydroxy-2H-1-benzopyran-2-one & 56.77 & 162 & $93-35-6$ & 0.234 \\
\hline 60 & 4-Hydroxy-9H-xanthen-9-one & 58.00 & 212 & $14686-63-6$ & 0.112 \\
\hline 61 & 9-Oxabicyclo[3.3.1]nonane-1,4-diol & 59.72 & 158 & $35377-88-9$ & 0.878 \\
\hline 62 & 2-Dibenzofuranol & 60.10 & 184 & $86-77-1$ & 0.175 \\
\hline 63 & 4,7-Dimethoxy-2-methyl-1H-indane? & 61.16 & 190 & - & 0.261 \\
\hline 64 & 1,2,3,5-Cyclohexantetraol & 61.53 & 148 & $53585-08-3$ & 4.257 \\
\hline 65 & Unknown & 62.07 & 148 & - & 2.152 \\
\hline 66 & 1,1'-Biphenyl-2,3-diol ? & 63.23 & 186 & $1133-63-7$ & 0.225 \\
\hline 67 & 2,5-Dihydroxy-7-oxabicyclo[3.2.1]oct-3-en-6-one & 64.30 & 156 & - & 1.789 \\
\hline 68 & Unknown & 64.74 & 156 & - & 1.307 \\
\hline 69 & Unknown & 65.33 & 156 & - & 0.177 \\
\hline
\end{tabular}

a Hydrogen, methane, ethylene, water were not analyzed due to the mass spectrometer settings.

b Hydroxybenzenes (phenols) detected in the pyrolyzate are in bold. 
Table 5. Rough estimation (\%) of the yield of dihydroxybenzenes produced in the pyrolyzates of several potential precursors from tobacco. $^{\mathrm{a}}$

\begin{tabular}{lccccccccc}
\hline & Chlorogenic acid & Rutin & Glucose & Cellulose & Starch & Pectin & Lignin \\
\hline Catechol & 7.38 & 1.22 & - & 0.13 & - & - & - \\
Hydroquinone & 3.87 & 0.02 & 0.21 & 0.32 & 0.15 & 0.08 & 0.27 \\
Resorcinol & 0.36 & 0.14 & 0.10 & 0.11 & 0.14 & 0.03 & - \\
3- + 4-Methylcatechol & 0.32 & 0.62 & - & - & - & - & - \\
Methylhydroquinone & - & - & - & - & - & - & - \\
Methylresorcinol & - & - & - & - & - & - & - \\
Ethylcatechol & 1.48 & - & - & - & - & - & - \\
\hline
\end{tabular}

a Both fructose and sucrose generated less than half of dihydroxybenzenes as compared to glucose. Also, caffeic acid is known to form catechol by pyrolysis (18), but its level in tobacco is very low compared to the other constituents.

Table 6. Rough estimation of the amount of dihydroxybenzenes produced in the pyrolyzates of several potential precursors from tobacco (result in $\mathrm{mg}$ ).

\begin{tabular}{l|c|c|c|c|c|c|c}
\hline & Chlorogenic acid & Rutin & Glucose & Cellulose & Starch & Pectin & Lignin \\
\hline Flue-cured level & 5.0 & 5.0 & 100.0 & 100.0 & 20.0 & 100.0 & 25.0 \\
\hline Catechol & 0.0369 & 0.0061 & - & 0.0130 & - & - & - \\
Hydroquinone & 0.0194 & 0.0001 & 0.0210 & 0.0320 & 0.0030 & 0.0080 & 0.0068 \\
Resorcinol & 0.0018 & 0.0007 & 0.0100 & 0.0110 & 0.0028 & 0.0030 & - \\
3- + 4-Methylcatechol & 0.0016 & 0.0031 & - & - & - & - & - \\
Methylhydroquinone & - & - & - & - & - & - & - \\
Methylresorcinol & - & - & - & - & - & - & - \\
Ethylcatechol & 0.0074 & - & - & - & - & - & - \\
\hline
\end{tabular}

This result is also in agreement with the finding reported in the literature (7) that chlorogenic acid is a major contributor to the formation of catechol in cigarette smoke, and leads to the conclusion that pectin, starch, and hemicellulose are not major catechol precursors as previously suggested in the literature (6).

Analysis of smoke from cigarettes made from a variety of tobaccos

For further understanding of the contribution of several tobacco constituents to the formation of dihydroxybenzenes, several single-grade tobacco cigarettes as well as $2 \mathrm{R} 4 \mathrm{~F}$ cigarettes, and a commercial cigarette were analyzed for chlorogenic acid and rutin. The single-grade tobacco cigarettes were manufactured at a pilot plant at R.J. Reynolds Tobacco Co. to constant tobacco weight. A list of these cigarettes is shown in Table 7. The main characteristics of these cigarettes are given in Table 8 . The results obtained for the levels of chlorogenic acid and rutin for the tobaccos listed in Table 7 are given in Table 9. These analyses were performed in triplicate. The relative standard deviation $\left(\mathrm{RSD}^{\circ}\right)$ ) for the measurements was approximately $5 \%$.

For the analysis of hydroquinone and catechol in smoke, a smoking regimen was first selected. For this purpose, a commercial cigarette (Commercial Ctrl.) was smoked in duplicate using each of the three regimens ISO, HCA and MTX. The results for TPM, hydroquinone, catechol as well as for the values of hydroquinone / TPM and catechol / TPM are given in Table 10. As expected, the values for hydroquinone / TPM and catechol / TPM were the
Table 7. List of single-grade tobacco cigarettes evaluated in the study.

\begin{tabular}{|c|c|c|}
\hline No & \begin{tabular}{|l}
$\begin{array}{l}\text { Tobacco } \\
\text { identification }\end{array}$ \\
\end{tabular} & Description \\
\hline 1 & L-FC A & Lower stalk (lug) flue-cured A \\
\hline 2 & U-FC A & $\begin{array}{l}\text { Upper stalk (leaf \& some tips) } \\
\text { flue-cured A }\end{array}$ \\
\hline 3 & L-FC B & Lower stalk (lug) flue-cured B \\
\hline 4 & U-FC B & $\begin{array}{l}\text { Upper stalk (leaf \& some tips) } \\
\text { flue-cured B }\end{array}$ \\
\hline 5 & Off L-FC & $\begin{array}{l}\text { Off shore, lower stalk (lugs \& primings) } \\
\text { flue-cured }\end{array}$ \\
\hline 6 & Off U-FC & $\begin{array}{l}\text { Off shore, upper stalk (leaf \& tips) } \\
\text { flue-cured }\end{array}$ \\
\hline 7 & L-By A & $\begin{array}{l}\text { Lower stalk (flyings \& cutters) } \\
\text { burley A }\end{array}$ \\
\hline 8 & U-By A & $\begin{array}{l}\text { Upper stalk (leaf) } \\
\text { burley } A\end{array}$ \\
\hline 9 & L-By B & $\begin{array}{l}\text { Lower stalk (flyings \& cutters) } \\
\text { burley B }\end{array}$ \\
\hline 10 & U-By B & $\begin{array}{l}\text { Upper stalk (leaf) } \\
\text { burley B }\end{array}$ \\
\hline 11 & Off L-By & $\begin{array}{l}\text { Off shore, lower stalk (flyings \& } \\
\text { cutters) burley }\end{array}$ \\
\hline 12 & Off U-By & $\begin{array}{l}\text { Off shore, upper stalk (leaf) } \\
\text { burley }\end{array}$ \\
\hline 13 & Or A & Oriental (middle to upper stalk) A \\
\hline 14 & Or B & Oriental (middle to upper stalk) B \\
\hline 15 & Commercial Ctrl. & Commercial cigarette \\
\hline
\end{tabular}

highest for ISO smoking, since the other types of smoking regimens generate a more diluted TPM material (mainly due to the contribution of water).

For this reason, further work necessary for comparing results was performed only using ISO smoking conditions. 
Table 8. The main characteristics of single-grade tobacco cigarettes.

\begin{tabular}{lcc}
\hline Physical property & Units & Target \\
\hline Dilution & $\%$ & 25.0 \\
Draft holes closed & $\mathrm{mm}$ & 155.0 \\
Draft holes open & $\mathrm{mm}$ & 125.0 \\
Cigarette length & $\mathrm{mm}$ & 83.0 \\
Rod length & $\mathrm{mm}$ & 56.0 \\
Filter length & $\mathrm{mm}$ & 27.0 \\
Circumference & $\mathrm{mm}$ & 24.48 \\
Rod density (for control only) & $\mathrm{g} / \mathrm{cc}$ & 0.2478 \\
Tobacco weight (for control only) & $\mathrm{g}$ & 0.6574 \\
Cigarette weight (for control only) & $\mathrm{g}$ & 0.9068 \\
\hline
\end{tabular}

Table 9. Levels of chlorogenic acid and rutin in tobacco samples.

\begin{tabular}{rl|c|c}
\hline No & $\begin{array}{l}\text { Tobacco } \\
\text { identification }\end{array}$ & $\begin{array}{c}\text { Chlorogenic acid } \\
(\mu \mathrm{g} / \mathrm{g})\end{array}$ & $\begin{array}{c}\text { Rutin } \\
(\mu \mathrm{g} / \mathrm{g})\end{array}$ \\
\hline 1 & L-FC A & 4473 & 2655 \\
2 & U-FC A & 4504 & 3576 \\
3 & L-FC B & 6340 & 3349 \\
4 & U-FC B & 6981 & 5425 \\
5 & Off L-FC & 9851 & 8055 \\
6 & Off U-FC & 7166 & 5376 \\
7 & L-By A & 134 & 386 \\
8 & U-By A & 160 & 490 \\
9 & L-By B & 94 & 169 \\
10 & U-By B & $>10$ & 80 \\
11 & Off L-By & 81 & 423 \\
12 & Off U-By & 60 & 380 \\
13 & Or A & 1139 & 2451 \\
14 & Or B & 6545 & 5883 \\
15 & Commercial Ctrl. & 4056 & 3516 \\
16 & 2R4F (handmade) ${ }^{\text {a }}$ & 3188 & 2323 \\
17 & 2R4F & 3218 & 2427 \\
\hline
\end{tabular}

a The $2 \mathrm{R} 4 \mathrm{~F}$ handmade cigarette used tobacco from $2 \mathrm{R} 4 \mathrm{~F}$ cigarettes that was treated with water, dried, conditioned, and remade into cigarettes using the same spills.

All cigarettes listed in Table 7 were smoked following the ISO protocol and analyzed by the HPLC technique described in the experimental section. The results for total particulate matter (TPM), hydroquinone and catechol measured in smoke are listed in Table 11. The results from Table 11 are given as averages of three replicate cigarettes. The RSD $\%$ for the analyses was approximately $10 \%$.
Because the level of cellulose in different types of tobaccos is not significantly different, and the contribution of mono and disaccharides is negligible for catechol formation (see Table 5) the differences in the yield of catechol in smoke were expected to depend significantly on the level of chlorogenic acid and rutin in the tobacco. To verify this point, the data from Tables 9 and 10, were used to generate plots representing the values of the level of catechol / TPM $(\mu \mathrm{g} / \mathrm{mg})$ as a function of chlorogenic acid / tobacco $(\mu \mathrm{g} / \mathrm{g})$ (shown in Figure 2), and representing the values of the level of catechol / TPM $(\mu \mathrm{g} / \mathrm{mg})$ as a function of rutin / tobacco $(\mu \mathrm{g} / \mathrm{g})$ (shown in Figure 3$)$.

The $\mathrm{R}^{2}$ of the trend line for the data in Figure 2 was only 0.5860 indicating a poor correlation between the catechol formation and the level of chlorogenic acid in tobacco. A similar poor correlation $\left(\mathrm{R}^{2}=0.6703\right)$ was obtained for the plot of the level of catechol / TPM $(\mu \mathrm{g} / \mathrm{mg})$ as a function of rutin / tobacco $(\mu \mathrm{g} / \mathrm{g})$. The correlation attempted for the levels of hydroquinone / TPM led to significantly weaker results when compared to the correlations for catechol.

The poor correlation values shown in Figures 2 and 3 did not support the results obtained from the pyrolysis study, and indicates that chlorogenic acid and rutin are not necessarily major contributors to the formation of catechol in cigarette smoke. This is in agreement with results reported in the literature (6) showing that only about $13 \%$ of catechol is generated from chlorogenic acid in a $1 \mathrm{R} 1$ cigarette. However, the results from Table 11 do not suggest that the difference may be caused by pectin, starch and hemicellulose (6) because they are at about the same level in different tobacco types.

\section{Addition of chlorogenic acid and rutin on several tobaccos, HPLC results}

Further work was considered necessary for the evaluation of the contribution to the formation of catechol and hydroquinone in smoke from chlorogenic acid and rutin in tobacco. This was done by adding exogenous chlorogenic acid (at two levels) and rutin to selected tobaccos, followed by making handmade cigarettes that were smoked and analyzed for catechol and hydroquinone by HPLC, and part of them for alkyl-dihydroxybenzenes using a GC/MS technique. For the addition of exogenous chlorogenic acid and rutin, five tobaccos were selected: 1. L-FC A, 7. L-By A, 13. Or A, 15. Ctrl., and 2R4F (see Table 7). For each treatment about $14 \mathrm{~g}$ of tobacco was removed from the cigarettes. One portion of tobacco was treated in a plastic bag with $15 \mathrm{~mL}$ water.

Table 10. Levels of TPM, hydroquinone, catechol, hydroquinone/TPM, and catechol/TPM for a commercial control cigarette smoked under different protocols.

\begin{tabular}{l|c|c|c|c|c|c}
\hline No & Smoking protocol & $\begin{array}{c}\text { TPM } \\
(\mathrm{mg} / \mathrm{cig})\end{array}$ & $\begin{array}{c}\text { Hydroquinone } \\
(\mu \mathrm{g} / \mathrm{cig})\end{array}$ & $\begin{array}{c}\text { Catechol } \\
(\mu \mathrm{g} / \mathrm{cig})\end{array}$ & $\begin{array}{c}\text { Hydroquinone/TPM } \\
(\mu \mathrm{g} / \mathrm{mg})\end{array}$ & $\begin{array}{c}\text { Catechol/TPM } \\
(\mu \mathrm{g} / \mathrm{mg})\end{array}$ \\
\hline 1 & HCA & 41.80 & 87.22 & 85.84 & 2.09 \\
2 & HCA & 40.07 & 80.60 & 78.25 & 2.05 \\
3 & ISO & 12.87 & 36.18 & 36.94 & 2.81 & 2.80 \\
4 & ISO & 11.93 & 33.36 & 33.84 & 2.87 \\
5 & MTX & 35.20 & 71.62 & 67.65 & 1.93 \\
6 & MTX & 32.70 & 65.06 & 62.99 & 1.92 \\
\hline
\end{tabular}




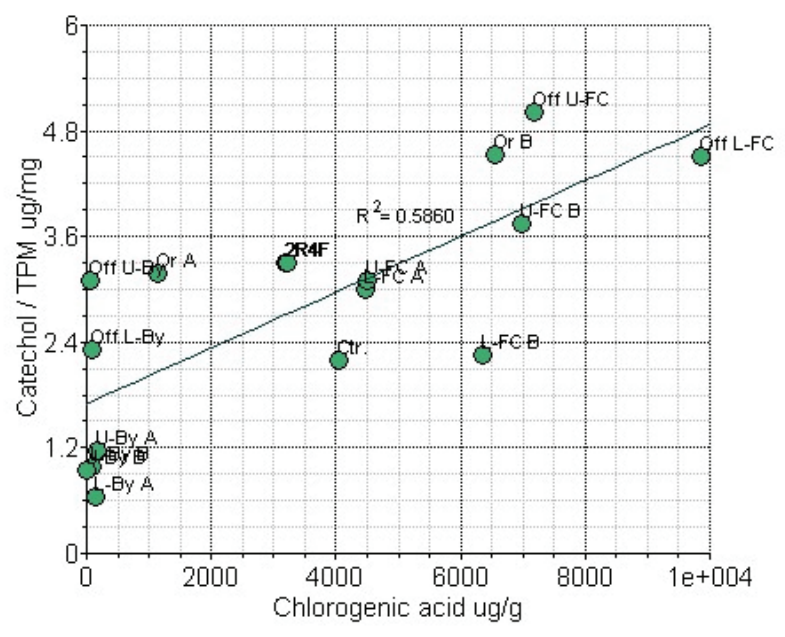

Figure 2. Plot representing the values of the level of catechol / TPM $(\mu \mathrm{g} / \mathrm{mg})$ as a function of chlorogenic acid/tobacco $(\mu \mathrm{g} / \mathrm{g})$.

Table 11. Levels of TPM, hydroquinone, and catechol.

\begin{tabular}{rl|r|r|r}
\hline No & $\begin{array}{l}\text { Tobacco } \\
\text { identification }\end{array}$ & $\begin{array}{c}\text { TPM } \\
(\mathrm{mg} / \mathrm{cig})\end{array}$ & $\begin{array}{c}\text { Hydroquinone } \\
(\mu \mathrm{g} / \mathrm{cig})\end{array}$ & $\begin{array}{c}\text { Catechol } \\
(\mu \mathrm{g} / \mathrm{cig})\end{array}$ \\
\hline 1 & L-FC A & 13.50 & 29.01 & 40.61 \\
2 & U-FC A & 15.88 & 54.42 & 49.18 \\
3 & L-FC B & 10.81 & 22.76 & 24.4 \\
4 & U-FC B & 16.62 & 68.83 & 62.34 \\
5 & Off L-FC & 11.44 & 55.97 & 51.61 \\
6 & Off U-FC & 14.91 & 71.13 & 74.71 \\
7 & L-By A & 11.93 & 0.00 & 7.70 \\
8 & U-By A & 14.15 & 10.37 & 16.44 \\
9 & L-By B & 12.36 & 7.33 & 12.19 \\
10 & U-By B & 13.27 & 3.78 & 12.44 \\
11 & Off L-By & 9.09 & 76.83 & 20.96 \\
12 & Off U-By & 9.13 & 75.35 & 28.35 \\
13 & Or A & 13.97 & 24.74 & 44.47 \\
14 & Or B & 14.53 & 39.39 & 65.87 \\
15 & Commercial Ctrl. & 12.40 & 34.77 & 35.39 \\
16 & 2R4F (handmade) & 9.10 & 22.20 & 30.00 \\
17 & 2R4F & 11.46 & 29.30 & 37.90 \\
\hline \multicolumn{2}{l}{} & & & \\
\hline
\end{tabular}

The cigarettes made later from this tobacco were used as the control for the cigarettes with added chlorogenic acid. Another portion of tobacco was treated with a $15 \mathrm{~mL}$ solution of chlorogenic acid (at two concentration levels, $4.7 \mathrm{~g} / \mathrm{mL}$ and $9.3 \mathrm{~g} / \mathrm{mL}$ ); another portion was treated with a $15 \mathrm{~mL}$ solution of rutin in ethanol. Tobacco necessary for making control cigarettes for rutin addition was treated with $15 \mathrm{~mL}$ ethanol. Each tobacco sample was allowed to soak in the solution/solvent for $30 \mathrm{~min}$, and was then kept in a conditioning chamber at $22{ }^{\circ} \mathrm{C}$ and $65 \%$ relative humidity for 48 hours. The tobacco was then handmade into cigarettes (using the initial spills). Each cigarette was made with $0.655 \mathrm{~g} \pm 10 \mathrm{mg}$ of tobacco. The cigarettes were conditioned and smoked as indicated in the experimental section. Part of the remaining tobacco was analyzed for chlorogenic acid and rutin content. The results regarding the analyzed levels of chlorogenic acid and rutin in each tobacco sample are given in Table 12.

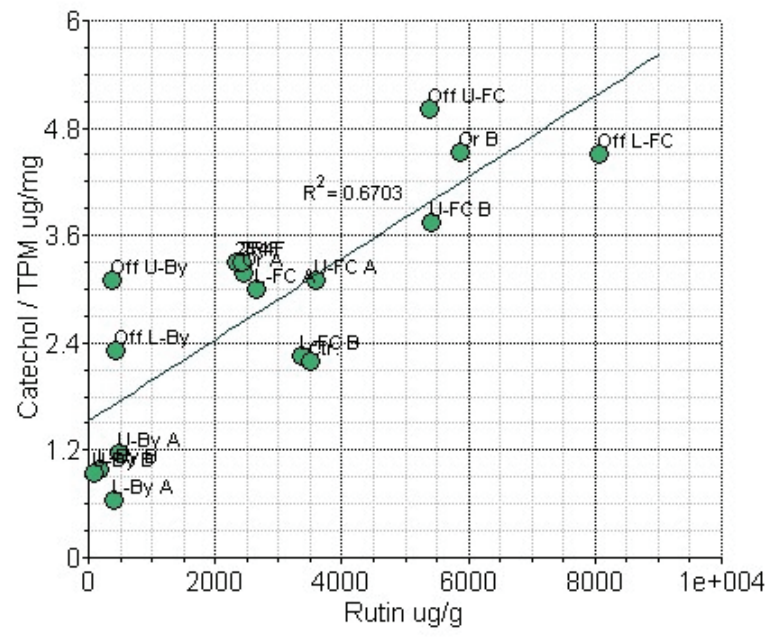

Figure 3. Plot representing the values of the level of catechol / TPM $(\mu \mathrm{g} / \mathrm{mg})$ as a function of rutin/tobacco $(\mu \mathrm{g} / \mathrm{g})$.

Each analysis was performed in duplicate. The RSD\% levels were approximately $0.4 \%$ for samples with additional chlorogenic acid and $2.3 \%$ for samples with added rutin. As seen from Table 12, the target of added $5 \mathrm{mg} / \mathrm{g}$ or $10 \mathrm{mg} / \mathrm{g}$ for either chlorogenic acid or rutin was not achieved. This is because part of the added solution remained on the walls of the plastic bag where the treatment was done and did not stay only on the tobacco. Therefore, lower levels than the target were not unexpected.

The results regarding the yields of TPM, catechol, and hydroquinone obtained for each cigarette are given in Table 13. Each analysis was performed in triplicate (of cigarettes) and the resulting $\mathrm{RSD} \%$ values were approximately $5.3 \%$ for hydroquinone measurements and $7.5 \%$ for catechol measurements. The data from Tables 11 and 12 were further used for the calculation of the resulting increase in hydroquinone and catechol yields upon the addition of chlorogenic acid and rutin to the tobacco. These results are shown in Table 14. Based on the increase in the yields of hydroquinone and catechol in smoke upon addition of chlorogenic acid or rutin to tobacco as given in Table 14, it was possible to back calculate the level of hydroquinone and catechol generated from the preexistent level of these compounds in cigarettes listed in Table 9. The results of back calculation are given in Table 15 for chlorogenic acid, and in Table 16 for rutin.

The results from Tables 15 and 16 show that both chlorogenic acid and rutin are contributors to the formation of hydroquinone and catechol in cigarette smoke, but their contribution is not as great as expected from the pyrolysis study. The percent contribution to the total catechol in smoke is in line with the finding reported in reference (6) (about 13\% for the 1R1 cigarette), but disagrees with those reported in reference (7). The relatively low contribution of chlorogenic acid and rutin as precursors to the formation of hydroquinone and catechol also explains the poor correlation between their level in tobacco and the level of hydroquinone and catechol in smoke.

Also, the estimated equal contribution of cellulose from different tobacco types to the formation of hydroquinone 
Table 12. Levels of chlorogenic acid and rutin in tobacco samples with added chlorogenic acid and rutin. ${ }^{a}$

\begin{tabular}{|c|c|c|c|c|c|}
\hline \multirow{2}{*}{ No } & \multirow{2}{*}{ Tobacco identification } & \multicolumn{2}{|c|}{ Chlorogenic acid $(\mu \mathrm{g} / \mathrm{g})$} & \multicolumn{2}{|c|}{ Rutin $(\mu \mathrm{g} / \mathrm{g})$} \\
\hline & & Added & Measured & Added & Measured \\
\hline 1 & L-FC A control & 0 & 4637.1 & 0 & 3158.5 \\
\hline $1 a$ & L-FC A + 5 chlorog & 5000 & 8676 & 0 & 3099.8 \\
\hline 7 & L-By A control & 0 & 0 & 0 & 247.7 \\
\hline $7 a$ & L-By A + 5 chlorog & 5000 & 3452.8 & 0 & 279.5 \\
\hline $7 b$ & L-By $A+5$ rutin & 0 & 112.7 & 5000 & 4271.6 \\
\hline 13 & Or A control & 0 & 923.2 & 0 & 2585.3 \\
\hline $13 a$ & Or $A+5$ chlorog & 5000 & 4223.8 & 0 & 1843.1 \\
\hline 15 & Ctrl. control & 0 & 3685.3 & 0 & 3230.9 \\
\hline $15 a$ & Ctrl. +5 chlorog & 5000 & 7351.9 & 0 & 2633.1 \\
\hline $2 \mathrm{R} 4 \mathrm{~F}$ & 2R4F control & 0 & 3188.6 & 0 & 2323.5 \\
\hline $2 \mathrm{R} 4 \mathrm{Fa}$ & $2 \mathrm{R} 4 \mathrm{~F}+5$ chlorog & 5000 & 7164.2 & 0 & 2062.4 \\
\hline $2 \mathrm{R} 4 \mathrm{Fb}$ & $2 \mathrm{R} 4 \mathrm{~F}+10$ chlorog. & 10.000 & 10962 & 0 & 2319.2 \\
\hline $2 \mathrm{R} 4 \mathrm{Fc}$ & $2 \mathrm{R} 4 \mathrm{~F}+5$ rutin & 0 & 3329.1 & 5000 & 6278.2 \\
\hline $2 \mathrm{R} 4 \mathrm{Fd}$ & $2 \mathrm{R} 4 \mathrm{~F}+10$ rutin & 0 & 3216.7 & 10.000 & 11261.7 \\
\hline
\end{tabular}

a The results for controls in Table 12 are reported for tobacco treated with water, and this explains some differences from the corresponding results in Table 9.

Table 13. Levels of catechol and hydroquinone in cigarettes with added chlorogenic acid and rutin. ${ }^{a}$

\begin{tabular}{ll|c|c|c|c|c}
\hline No & Tobacco identification & $\begin{array}{c}\text { TPM } \\
(\mathrm{mg} / \mathrm{cig})\end{array}$ & $\begin{array}{c}\text { Hydroquinone } \\
(\mu \mathrm{g} / \mathrm{cig})\end{array}$ & $\begin{array}{c}\text { Catechol } \\
(\mu \mathrm{g} / \mathrm{cig})\end{array}$ & $\begin{array}{c}\text { Hydroquinone/TPM } \\
(\mu \mathrm{g} / \mathrm{mg})\end{array}$ & $\begin{array}{c}\text { Catechol/TPM } \\
(\mu \mathrm{g} / \mathrm{mg})\end{array}$ \\
\hline 1 & L-FC A control & 11.6 & 23.6 & 43.0 & 2.035 & 3.707 \\
1a & L-FC A + 5 chlorog & 11.5 & 24.7 & 46.0 & 2.148 & 4.000 \\
7 & L-By A control & 10.6 & 9.7 & 4.4 & 0.915 & 0.415 \\
7a & L-By A + 5 chlorog & 9.3 & 9.6 & 6.6 & 1.032 & 0.713 \\
7b & L-By A + 5 rutin & 10.6 & 11.8 & 6.2 & 1.113 & 0.585 \\
13 & Or A control & 10.9 & 19.8 & 34.4 & 1.817 & 3.156 \\
13a & Or A + 5 chlorog & 10.9 & 22.3 & 39.3 & 2.046 & 3.606 \\
15 & Ctrl. control & 11.5 & 26.7 & 31.2 & 2.322 & 2.713 \\
15a & Ctrl. + 5 chlorog & 11.3 & 28.9 & 35.7 & 2.823 & 3.159 \\
2R4F & 2R4F control & 9.1 & 22.2 & 30.0 & 2.439 & 3.297 \\
2R4Fa & 2R4F + 5 chlorog & 9.1 & 23.6 & 32.5 & 2.594 & 3.571 \\
2R4Fb & 2R4F + 10 chlorog. & 8.1 & 24.4 & 32.3 & 3.012 & 3.988 \\
2R4Fc & 2R4F + 5 rutin & 8.3 & 21.9 & 29.3 & 2.639 & 3.530 \\
2R4Fd & 2R4F + 10 rutin & 9.3 & 27.0 & 35.3 & 2.903 & 3.796 \\
\hline
\end{tabular}

a The results for controls in Table 13 are reported for handmade cigarettes from tobacco treated with water, and this explains some differences from the corresponding results in Table 11.

Table 14. Increase in hydroquinone and catechol in smoke upon the addition of chlorogenic acid and rutin to tobacco.

\begin{tabular}{ll|c|c|c|c}
\hline No & Tobacco identification & $\begin{array}{c}\text { Additional } \\
\text { chlorogenic acid } \\
(\mu \mathrm{g} / \mathrm{g})\end{array}$ & $\begin{array}{c}\text { Additional rutin } \\
(\mu \mathrm{g} / \mathrm{g})\end{array}$ & $\begin{array}{c}\text { Increased } \\
\text { hydroquinone/TPM } \\
(\mu \mathrm{\mu} / \mathrm{mg})\end{array}$ & $\begin{array}{c}\text { Increased catechol/TPM } \\
(\mu \mathrm{g} / \mathrm{mg})\end{array}$ \\
\hline 1a & L-FC A + 5 chlorog & 4038.9 & 0 & 0.113 & 0.293 \\
7a & L-By A + 5 chlorog & 3452.8 & 0 & 0.117 & 0.298 \\
13a & Or A + 5 chlorog & 3300.6 & 0 & 0.229 & 0.450 \\
15a & Ctrl. + 5 chlorog & 3666.6 & 0 & 0.236 & 0.446 \\
2R4Fa & 2R4F + 5 chlorog & 3975.6 & 0 & 0.154 & 0.275 \\
2R4Fb & 2R4F + 10 chlorog. & 7773.4 & 0 & 0.573 & 0.691 \\
7b & L-By A + 5 rutin & 0 & 4023.9 & 0.198 & 0.170 \\
2R4Fc & 2R4F + 5 rutin & 0 & 3954.7 & 0.200 & 0.233 \\
2R4Fd & 2R4F + 10 rutin & 0 & 8938.2 & 0.464 & 0.499 \\
\hline
\end{tabular}


Table 15. Calculation of the contribution of chlorogenic acid to the formation of hydroquinone and catechol in smoke.

\begin{tabular}{|c|c|c|c|c|c|c|c|c|}
\hline \multirow{2}{*}{ No } & \multirow{2}{*}{\begin{tabular}{|l} 
Tobacco \\
identification
\end{tabular}} & \multirow{2}{*}{$\begin{array}{c}\text { Tobacco } \\
\text { chlorogenic acid } \\
(\mu \mathrm{g} / \mathrm{g})\end{array}$} & \multirow{2}{*}{\begin{tabular}{|c|}
$\begin{array}{c}\text { Hydroquinone } \\
\text { TPM } \\
(\mu \mathrm{g} / \mathrm{mg})\end{array}$ \\
\end{tabular}} & \multicolumn{2}{|c|}{ Hydroquinone from chlorog. } & \multirow{2}{*}{$\begin{array}{c}\text { Catechol/ } \\
\text { TPM } \\
(\mu \mathrm{g} / \mathrm{mg})\end{array}$} & \multicolumn{2}{|c|}{ Catechol from chlorog. } \\
\hline & & & & $(\mu \mathrm{g} / \mathrm{mg})$ & $\%$ & & $(\mu \mathrm{g} / \mathrm{mg})$ & $(\%)$ \\
\hline 1 & L-FC A & 4473 & 2.149 & 0.262 & 12.20 & 3.008 & 0.398 & 13.23 \\
\hline 2 & U-FC A & 4504 & 3.427 & 0.264 & 7.70 & 3.097 & 0.400 & 12.92 \\
\hline 3 & L-FC B & 6340 & 2.105 & 0.372 & 17.65 & 2.257 & 0.564 & 24.99 \\
\hline 4 & U-FC B & 6981 & 4.141 & 0.409 & 9.88 & 3.751 & 0.621 & 16.56 \\
\hline 5 & Off L-FC & 9851 & 4.892 & 0.577 & 11.80 & 4.511 & 0.876 & 19.42 \\
\hline 6 & Off U-FC & 7166 & 4.771 & 0.420 & 8.80 & 5.011 & 0.637 & 12.71 \\
\hline 7 & L-By A & 134 & 0.000 & 0.008 & 0.00 & 0.645 & 0.012 & 1.86 \\
\hline 8 & U-By A & 160 & 0.733 & 0.009 & 1.28 & 1.162 & 0.014 & 1.20 \\
\hline 9 & L-By B & 94 & 0.593 & 0.006 & 0.93 & 0.986 & 0.008 & 0.81 \\
\hline 10 & U-By B & $>10$ & 0.285 & 0.001 & 0.21 & 0.937 & 0.001 & 0.11 \\
\hline 11 & Off L-By & 81 & 8.452 & 0.005 & 0.06 & 2.306 & 0.007 & 0.30 \\
\hline 12 & Off U-By & 60 & 8.253 & 0.004 & 0.04 & 3.105 & 0.005 & 0.16 \\
\hline 13 & Or A & 1139 & 1.771 & 0.067 & 3.77 & 3.183 & 0.101 & 3.17 \\
\hline 14 & Or B & 6545 & 2.711 & 0.384 & 14.15 & 4.533 & 0.582 & 12.84 \\
\hline 15 & Ctrl. & 4056 & 2.804 & 0.338 & 12.05 & 2.854 & 0.361 & 12.65 \\
\hline 16 & 2R4F (hand) & 3188 & 2.557 & 0.187 & 7.31 & 3.307 & 0.283 & 8.58 \\
\hline 17 & 2R4F & 3218 & 2.440 & 0.189 & 7.73 & 3.297 & 0.286 & 8.65 \\
\hline
\end{tabular}

Table 16. Calculation of the contribution of rutin to the formation of hydroquinone and catechol in smoke.

\begin{tabular}{|c|c|c|c|c|c|c|c|c|}
\hline \multirow{2}{*}{ No } & \multirow{2}{*}{$\begin{array}{l}\text { Tobacco } \\
\text { identification }\end{array}$} & \multirow{2}{*}{$\begin{array}{c}\text { Tobacco rutin } \\
(\mu \mathrm{g} / \mathrm{g})\end{array}$} & \multirow{2}{*}{$\begin{array}{c}\text { Hydroquinone/ } \\
\text { TPM } \\
(\mu \mathrm{g} / \mathrm{mg})\end{array}$} & \multicolumn{2}{|c|}{ Hydroquinone from rutin } & \multirow{2}{*}{$\begin{array}{c}\text { Catechol/ } \\
\text { TPM } \\
(\mu \mathrm{g} / \mathrm{mg})\end{array}$} & \multicolumn{2}{|c|}{ Catechol from rutin } \\
\hline & & & & $(\mu \mathrm{g} / \mathrm{mg})$ & $(\%)$ & & $(\mu \mathrm{g} / \mathrm{mg})$ & $(\%)$ \\
\hline 1 & L-FC A & 2655 & 2.149 & 6.28 & 6.30 & 3.008 & 0.133 & 4.42 \\
\hline 2 & U-FC A & 3576 & 3.427 & 5.31 & 5.32 & 3.097 & 0.179 & 5.78 \\
\hline 3 & L-FC B & 3349 & 2.105 & 8.12 & 8.11 & 2.257 & 0.168 & 7.44 \\
\hline 4 & U-FC B & 5425 & 4.141 & 6.67 & 6.68 & 3.751 & 0.272 & 7.25 \\
\hline 5 & Off L-FC & 8055 & 4.892 & 8.38 & 8.39 & 4.511 & 0.404 & 8.96 \\
\hline 6 & Off U-FC & 5376 & 4.771 & 5.74 & 5.74 & 5.011 & 0.270 & 5.39 \\
\hline 7 & L-By A & 386 & 0.000 & 0.00 & 0.00 & 0.645 & 0.019 & 2.95 \\
\hline 8 & U-By A & 490 & 0.733 & 3.41 & 3.41 & 1.162 & 0.025 & 2.15 \\
\hline 9 & L-By B & 169 & 0.593 & 1.52 & 1.45 & 0.986 & 0.008 & 0.81 \\
\hline 10 & U-By B & 80 & 0.285 & 1.40 & 1.43 & 0.937 & 0.004 & 0.43 \\
\hline 11 & Off L-By & 423 & 8.452 & 0.26 & 0.26 & 2.306 & 0.021 & 0.91 \\
\hline 12 & Off U-By & 380 & 8.253 & 0.23 & 0.23 & 3.105 & 0.019 & 0.61 \\
\hline 13 & Or A & 2451 & 1.771 & 7.06 & 7.05 & 3.183 & 0.123 & 3.86 \\
\hline 14 & Or B & 5883 & 2.711 & 11.07 & 11.06 & 4.533 & 0.295 & 6.51 \\
\hline 15 & Ctrl. & 3516 & 2.804 & 6.38 & 9.26 & 2.854 & 0.176 & 6.17 \\
\hline 16 & 2R4F (hand) & 2323 & 2.557 & 4.61 & 4.63 & 3.307 & 0.117 & 3.54 \\
\hline 17 & $2 \mathrm{R} 4 \mathrm{~F}$ & 2427 & 2.440 & 5.08 & 5.07 & 3.297 & 0.122 & 3.70 \\
\hline
\end{tabular}

Table 17. Results from GC/MS analysis for two cigarettes with added chlorogenic acid or rutin (analyte/TPM $\mu \mathrm{g} / \mathrm{mg}$ ).

\begin{tabular}{lccccc|c|c}
\hline Analyte & L-By A control & L-By A + 5 chlorog. & L-By A + 5 rutin & 2R4F control & 2R4F + 5 chlorog. & 2R4F + 5 rutin \\
\hline Catechol & 0.47 & 0.61 & 0.52 & 3.29 & 3.55 & 3.42 \\
Resorcinol & 0.01 & 0.02 & 0.01 & 0.08 & 0.07 & 0.09 \\
4-Methylcatechol & 0.05 & 0.05 & 0.05 & 0.39 & 0.43 & 0.42 \\
Hydroquinone & 1.17 & 1.24 & 1.19 & 2.26 & 2.43 & 2.45 \\
3-Methylcatechol & 0.03 & 0.04 & 0.04 & 0.27 & 0.27 & 0.25 \\
4-Ethylcatechol & 0.04 & 0.11 & 0.05 & 0.23 & 0.33 & 0.25 \\
3-Ethylcatechol & 0.06 & 0.07 & 0.07 & 0.23 & 0.22 & 0.24 \\
\hline
\end{tabular}


and catechol, and the minor contribution of reducing sugars, indicates that other unidentified tobacco components, which are at higher levels in particular in fluecured tobaccos, are also contributing to the formation of dihydroxybenzenes.

\section{Results on GC/MS analyses}

The GC/MS analysis was performed on only a limited number of samples, including samples 7. (L-By A), 7a. (LBy A +5 chlorog.), and 7b. (L-By A +5 rutin), and samples (2R4F), (2R4F +5 chlorog.), and ( $2 \mathrm{R} 4 \mathrm{~F}+5$ rutin). The results for several hydroxybenzenes reported to TPM values are given in Table 16. The results from Table 16 are in fairly good agreement for those obtained by HPLC analysis for catechol and hydroquinone. The other results indicate that only 4-ethylcatechol is significantly increased by the addition of chlorogenic acid. Some increase of 4-ethylcatechol is also seen for the addition of rutin, but it is not very large.

\section{CONCLUSIONS}

The present study evaluated the contribution of chlorogenic acid and rutin to the formation of dihydroxybenzenes in cigarette smoke. The results showed that for a variety of single-grade tobacco cigarettes and for two blended cigarettes (one being 2R4F Kentucky reference), the contribution of chlorogenic acid and rutin to the formation of catechol and hydroquinone depends on the blend. For the 2R4F cigarette, the contributions from chlorogenic acid were $8.7 \%$ for catechol, and $7.7 \%$ for hydroquinone (in ISO smoking protocol). For the same cigarette, the contributions from rutin were $3.7 \%$ for catechol, and $5.1 \%$ for hydroquinone.

The results are in line with a previously reported result (6) indicating that chlorogenic acid has a contribution of about $13 \%$ to the catechol formation in the $1 \mathrm{R} 1$ cigarette. The study also suggests that other unidentified compounds in tobacco, besides chlorogenic acid, rutin, glucose, fructose, sucrose, cellulose, pectin, starch and lignin are major contributors to the formation of catechol and hydroquinone in cigarette smoke.

\section{REFERENCES}

1. Kaur, N., M. Lacasse, A. Fürtös, K.C. Waldron, and A. Morin: Sequential fractionation with concurrent chemical and toxicological characterization of the combustion products of chlorogenic acid; J. Chromatogr. A 1216 (2009) 4703-4712.

2. Chouchane, S., J.B. Wooten, F.J. Tewes, A. Wittig, B.P. Müller, D. Veltel, and J. Diekmann: Involvement of semiquinone radicals in the in vitro cytotoxicity of cigarette mainstream smoke; Chem. Res. Toxicol. 19 (2006) 1602-1610.

3. Gopalakrishna, R., Z.-H. Chen, and U. Gundimeda: Tobacco smoke tumor promoters, catechol and hydroquinone, induce oxidative regulation of protein kinase $\mathrm{C}$ and influence invasion and metastasis of lung carcinoma cells; Proc. Natl. Acad. Sci. 91 (1994) $12233-12237$.

4. Lau, S.S., T.J. Monks, J.I. Everitt, E. Kleymenova, and C.L. Walker: Carcinogenicity of a nephrotoxic metabolite of the "nongenotoxic" carcinogen hydroquinone; Chem. Res. Toxicol. 14 (2001) 25-33.

5. http://potency.berkeley.edu/chemnameindex.html (accessed June 2012)

6. Carmella, S.G., S.S. Hecht, T.C. Tso, and D. Hoffmann: Roles of tobacco cellulose, sugars and chlorogenic acid as precursors to catechol in cigarette smoke; J. Agric. Food Chem., 32 (1964) 267-273.

7. Schlotzhauer, W.S., M.E. Snook, O.T. Chortyk, and R.L. Wilson: Pyrolytic evaluation of low chlorogenic acid tobaccos in the formation of the tobacco smoke co-carcinogen catechol; J. Anal. Appl. Pyrol. 22 (1992) 231-238.

8. Schlotzhauer, W.S. and O.T. Chortyk: Pyrolytic studies on the origin of phenolic compounds in tobacco smoke; Tob. Sci. 25 (1981) 6-10.

9. McGrath, T.E., A.P. Brown, N.K. Meruva, and W.G. Chan: Phenolic compound formation from the low temperature pyrolysis of tobacco; J. Anal. Appl. Pyrol. 84 (2009) 170-178.

10. Dyakonov, A.J., R.T. Walker, C.A. Brown, F.R. Perini, D.S. Passer, J. Guan, and E.A. Robinson: Studies of the Formation of Smoke Phenols; Beitr. Tabakforsch. Int. 23 (2008) 68-84.

11. Liu, C., Y. DeGrandpré, A. Porter, A. Griffiths, K. McAdam, R. Voisine, F. Côté, and C. Proctor: The use of a novel tobacco treatment process to reduce toxicant yields in cigarette smoke; Food Chem. Toxicol. 49 (2011) 1904-1917.

12. Baker, R.R. and L.J. Bishop: The pyrolysis of tobacco ingredients; J. Anal. Appl. Pyrol. 71 (2004) 223-311.

13. International Organisation for Standardization (ISO): ISO 3308:1991 Routine analytical cigarette smoking machine- definitions and standard conditions (E); ISO, Geneva, Switzerland, 1991.

14. International Organisation for Standardization (ISO): ISO 4387:1991 Cigarette - Determination of total and nicotine free dry particulate matter using a routine analytical smoking machine (E); ISO, Geneva, Switzerland, 1991.

15. Moldoveanu, S.C. and M. Kiser: Gas chromatography/mass spectrometry versus liquid chromatography/fluorescence detection in the analysis of phenols in mainstream cigarette smoke; J. Chromatogr. A. 1141 (2007) 90-97.

16. Moldoveanu, S.C.: Analytical pyrolysis of natural organic polymers; Elsevier, Amsterdam, 1998, pp. 53-54.

17. Jenkins Jr., R.W., R.H. Newman, and M.K. Chavis: Cigarette Smoke Formation Studies: II. Smoke Distribution and Mainstream Pyrolytic Composition of Added ${ }^{14} \mathrm{C}$-Menthol (U); Beitr. Tabakforsch. 5 (1970) 299-301.

18. Moldoveanu, S.C.: Pyrolysis of organic molecules with applications to health and environmental issues; Elsevier, Amsterdam, 2010, pp. 298-305.

19. Stotesbury, S.J., H. Digard, L.J. Willoughby, and A. Couch: The Pyrolysis of Tobacco Additives as a 
Means of Predicting Their Behavior in a Burning Cigarette; Beitr. Tabakforsch. Int. 18 (1999) 147-163.

20. Leffingwell, J.C.: Leaf Chemistry; in: Tobacco Production, Chemistry and Technology, edited by D.L. Davis and M.T. Nielsen, Blackwell Science, Berlin, 1988, pp. 265-284.

21. Rodgman, A. and T.A. Perfetti: The Chemical Components of Tobacco and Tobacco Smoke; CRC Press, Boca Raton, 2009, FL, p. 1126.

22. Perfetti, T.A. and A. Rodgman: The Complexity of Tobacco and Tobacco Smoke; Beitr. Tabakforsch. Int. 24 (2011) 215-232.

23. De Smet, R., J. Van Kaer, B. Van Vlem, A. De Cubber, P. Brunet, N. Lamaire, and R. Vanholder: Toxicity of free $p$-cresol: A prospective and cross-sectional analysis; Clin. Chem. 49 (2003) 470-478.
24. Chen, P.X. and S.C. Moldoveanu: Mainstream Smoke Chemical Analyses for 2R4F Kentucky Reference Cigarette; Beitr. Tabakforsch. Int. 20 (2003) 448-458.

\section{Corresponding author}

Serban C. Moldoveanu

R.J. Reynolds Tobacco Co.

Winston-Salem, NC 27105

USA

E-mail:moldovs@rjrt.com 